\title{
Pengaruh Model Pembelajaran Problem Based Learning Terhadap Kemampuan Pemecahan Masalah Matematis Ditinjau dari Self Regulated Learning Siswa
}

\author{
Musliha $^{1}$, Rena Revita ${ }^{1^{*}}$ \\ ${ }^{1}$ Program Studi Pendidikan Matematika, UIN Sultan Syarif Kasim Riau \\ *Corresponding Author: rena.revita@uin-suska.ac.id
}

\begin{tabular}{|c|c|}
\hline ARTICLE INFO & ABSTRACT \\
\hline $\begin{array}{l}\text { Article bistory: } \\
\text { Received } 5 \text { Jan } 2021 \\
\text { Revised } 19 \text { May } 2021 \\
\text { Accepted } 20 \text { May } 2021 \\
\text { Keywords: } \\
\text { Problem Based } \\
\text { Learning, Mathematical } \\
\text { Problem-Solving } \\
\text { Ability, Self-Regulated } \\
\text { Learning }\end{array}$ & $\begin{array}{l}\text { This research aimed to know the effect of implementing the Problem Based } \\
\text { Learning model toward students' mathematical problem-solving ability } \\
\text { derived from their self-regulated learning at MTs Rokan Hulu. This research } \\
\text { using a factorial experiment design. By random cluster sampling, 8th-grade } \\
\text { students of A-class as the experimental and C-class students as the control } \\
\text { group. Data were collected from the mathematical problem-solving ability } \\
\text { test and self-regulated learning questionnaire. The result of this study is: 1) } \\
\text { there was a difference in mathematical problem-solving ability between } \\
\text { students taught by Problem Based Learning model and those who educated } \\
\text { by direct learning, 2) there was a difference in mathematical problem-solving } \\
\text { ability among students having high, medium and low self-regulated learning, } \\
\text { and 3) there was no interaction between Problem Based Learning model and } \\
\text { student mathematical problem-solving ability. }\end{array}$ \\
\hline
\end{tabular}

(C) 2021 The Author(s)

Published by JRPM (Jurnal Review Pembelajaran Matematika)

This is an open access article under CC BY-SA license (https://creativecommons.org/licenses/by-sa/4.0/)

How to cite:

Musliha, M. \& Revita, R. (2021). Pengaruh Model Pembelajaran Problem Based Learning Terhadap Kemampuan Pemecahan Masalah Matematis Ditinjau dari Self Regulated Learning Siswa. JRPM (Jurnal Review Pembelajaran Matematika), 6(1), 68-82.

\section{PENDAHULUAN}

Kemampuan pemecahan masalah matematis merupakan kemampuan yang sangat penting dan perlu dikuasai oleh siswa dalam belajar matematika (Hendriana et al., 2017; Riati \& Farida, 2017). Kemampuan pemecahan masalah matematis, yaitu kemampuan menunjukkan sikap logis, kritis, analitis, kreatif, cermat dan teliti, bertanggung jawab, responsif, dan tidak mudah menyerah dalam menyelesaikan masalah (Permendikbud, 2016; National Council of Teachers of Matematics, 2016). Idealnya semua siswa baik jenjang dasar, menengah, maupun tinggi harus memiliki kemampuan pemecahan masalah matematis.

Untuk mendapatkan hasil yang baik, dalam belajar matematika terdapat faktor-faktor yang ikut mempengaruhi. Faktor-faktor yang mempengaruhi belajar siswa tersebut dibedakan 
menjadi 3 macam, yakni: a) Faktor internal (faktor dari dalam siswa), yakni keadaan/kondisi jasmani dan rohani siswa, b) Faktor eksternal (faktor dari luar siswa), yakni kondisi lingkungan di sekitar siswa, c) Faktor pendekatan pembelajaran, yakni jenis upaya belajar siswa yang meliputi strategi dan metode yang digunakan untuk mempelajari pelajaran (Syah, 2006).

Berdasarkan dari faktor-faktor yang mempengaruhi hasil belajar siswa, maka guru sangat berperan penting dalam mendorong terjadinya proses belajar yang optimal melalui model, metode maupun pendekatan yang diterapkan. Hal ini sejalan dengan persyaratan yang dijelaskan Syah (2009) bahwa salah satu faktor yang mempengaruhi hasil belajar siswa adalah strategi, pendekatan dan metode yang digunakan guru dalam membantu siswa untuk mempelajari materi-materi pelajaran yang diberikan.

Sanjaya (2006) juga berpendapat bahwa salah satu masalah yang dihadapi di dunia pendidikan kita adalah lemahnya proses pembelajaran, dimana anak kurang didorong untuk mengembangkan kemampuan berpikir. Oleh sebab itu diperlukan upaya untuk dapat mengubah suasana pembelajaran lebih menarik. Salah satu upaya yang dapat dilakukan, yaitu dengan mengubah model pembelajaran (Nisak \& Istiana, 2017). Adapun salah satu model pembelajaran yang meningkatkan kemampuan pemecahan masalah matematis siswa adalah model pembelajaran problem based learning. Hal ini diperkuat dengan adanya penelitian relevan yang dilakukan oleh Nadhifah \& Afriansyah (2016) menyatakan bahwa model pembelajaran problem based learning dapat meningkatkan kemampuan pemecahan masalah matematis siswa.

Problem based learning merupakan model pembelajaran yang menghadapkan siswa pada suatu masalah sehingga siswa dapat mengembangkan kemampuan berpikir tingkat tinggi dan keterampilan penyelesaian masalah serta memperoleh pengetahuan baru terkait dengan permasalahan tersebut (Lestari \& Yudhanegara, 2015). Model pembelajaran tersebut melatih siswa menjadi lebih aktif dalam menyampaikan, menanyakan, dan memahami materi yang diajarkan, sehingga terciptalah suatu lingkungan belajar yang menyenangkan bagi siswa. Lingkungan belajar yang menyenangkan dapat memunculkan motivasi pada diri siswa sehingga dapat mempengaruhi kemampuan siswa dalam memecahkan masalah.

Faktor lain yang juga mempengaruhi keberhasilan dalam pembelajaran adalah kemandirian belajar siswa (self regulated learning). Self regulated learning adalah kemampuan seseorang untuk mengelola secara efektif pengalaman belajarnya sendiri di dalam berbagai cara sehingga mencapai hasil belajar yang optimal (Amir \& Risnawati, 2015). Sedangkan Hendriana et al. (2017) menjelasakan bahwa self regulated learning merupakan suatu proses 
dimana individu berinisiatif belajar dengan atau tanpa bantuan orang lain, mendiagnosa kebutuhan belajarnya sendiri, merumuskan tujuan belajar, mengidentifikasi sumber belajar yang dapat digunakannya, memilih dan menerapkan strategi belajar dan mengevaluasi hasil belajarnya. Kemandirian belajar siswa (self regulated learning) memiliki peranan penting dalam prestasi akademik yang dicapai siswa, salah satunya dipengaruhi oleh kepercayaan diri siswa terhadap kemampuannya (Lestari \& Yudhanegara, 2015).

Penelitian tentang pemecahan masalah telah banyak dilakukan. Azizah, Maimunah \& Roza (2019) menyatakan bahwa kemampuan pemecahan masalah sesuai dengan level self regulated learningnya. Semakin tinggi level self regulated learningnya maka semakin tinggi kemampuan pemecahan masalahnya, begitu juga sebaliknya. Kurnila, Jau, Fedi, \& Kurniawan (2018) menyatakan bahwa dalam membelajarkan pemecahan masalah harus menggunakan model pembelajaran tertentu seperti Number Head Together (NHT) dan pendekatan saintifik, karena hal ini berpengaruh terhadap kemampuan komunikasi matematika. Perbedaan penelitian ini dengan penelitian sebelumnya yaitu model pembelajaran yang digunakan dalam membelajarkan pemecahan masalah siswa self regulated learning yaitu menggunakan model pembelajaran problem based learning. Oleh karena itu, terdapat 3 (tiga) tujuan dari penelitian ini yaitu: (1) untuk mengetahui ada tidaknya perbedaan kemampuan pemecahan masalah matematis antara siswa yang mengikuti model pembelajaran problem based learning dan siswa yang mengikuti pembelajaran langsung; (2) untuk mengetahui ada tidaknya perbedaan kemampuan pemecahan masalah matematis pada siswa yang memiliki self regulated learning tinggi, sedang, dan rendah; (3) untuk mengetahui ada tidaknya interaksi antara model pembelajaran problem based learning terhadap kemampuan pemecahan masalah matematis siswa.

\section{METODE PENELITIAN}

Penelitian ini merupakan penelitian kuantitatif yang bersifat design factorial exsperiment. Populasi dalam penelitian ini adalah seluruh siswa kelas VIII Madrasah Tsanawiyah di Rokan Hulu tahun ajaran 2020/2021 yang terdiri dari 4 kelas. Pengambilan sampel ini dilakukan menggunakan teknik cluster random sampling yaitu teknik pengambilan sampel yang terdiri dari sekelompok anggota yang terhimpun pada kelompok (cluster) secara acak (Hartono, 2019).

Proses pengambilan sampel dimulai dengan mengidentifikasi nilai ulangan harian dari empat kelas sebagai populasi penelitian kemudian dilakukan uji normalitas dan uji homogenitas. Hasil perhitungan menunjukkan empat kelas tersebut berdistribusi normal dan 
memiliki varians homogen. Selanjutnya dilakukan uji anova satu arah yang menunjukkan bahwa tidak terdapat perbedaan kemampuan siswa dari keempat kelas tersebut. Sehingga dari empat kelas tersebut bisa dilakukan pengambilan sampel secara acak (cluster random sampling). Dengan menggunakan teknik undian diperoleh kelas VIII A sebagai kelas eksperimen dan kelas VIII C sebagai kelas kontrol.

Teknik pengumpulan data yang digunakan dalam penelitian ini adalah teknik tes dan non tes. Adapun teknik tes yang digunakan peneliti yaitu tes soal kemampuan pemecahan masalah matematis yang terdiri dari pretest dan posttest. Sedangkan teknik non tes yang digunakan peneliti adalah angket. Teknik angket digunakan untuk mengukur self regulated learning (kemandirian belajar siswa) dengan menggunakan instrumen angket yang berskala Likert. Skala ini untuk menilai sikap atau tingkah laku yang diinginkan peneliti dengan cara mengajukan beberapa pernyataan dengan empat pilihan yang akan diberikan yaitu sangat setuju, setuju, tidak setuju dan sangat tidak setuju kepada responden. Adapun penskoran skala likert, jawaban diberi bobot atau disamakan dengan nilai 4, 3, 2, 1 untuk empat pilihan pernyataan positif sedangkan 1, 2, 3, 4 untuk pernyataan negatif. Selanjutnya siswa dikelompokkan berdasarkan self regulated learning tinggi, sedang dan rendah.

Adapun sesuai dengan tujuan dalam penelitian ini, maka teknik yang digunakan untuk menganalisis data uji hipotesis 1, 2 dan 3, digunakan ANOVA dua arah (two ways anova). Tujuan dilakukan uji hipotesis ini adalah untuk mengetahui ada tidaknya perbedaan kemampuan pemecahan masalah matematis antara siswa yang mengikuti model pembelajaran problem based learning dan siswa yang mengikuti pembelajaran langsung, ada tidaknya perbedaan kemampuan pemecahan masalah matematis pada siswa yang memiliki self regulated learning tinggi, sedang dan rendah, serta ada tidaknya interaksi antara model pembelajaran problem based learning terhadap kemampuan pemecahan masalah matematis siswa. Selanjutnya sebelum dilakukan uji anova dua arah, terlebih dahulu dilakukan uji prasyarat yaitu uji normalitas dan uji homogenitas.

\section{HASIL DAN PEMBAHASAN}

Sebelum peneliti menerapkan model pembelajaran problem based learning terlebih dahulu peneliti memberikan soal kemampuan pemecahan masalah matematis (pretest). Adapun hasil nilai rata-rata kemampuan pemecahan masalah matematis siswa yang diberikan sebelum adanya perlakuan (pretest) dan setelah adanya perlakuan (posttest) disajikan pada diagram berikut: 


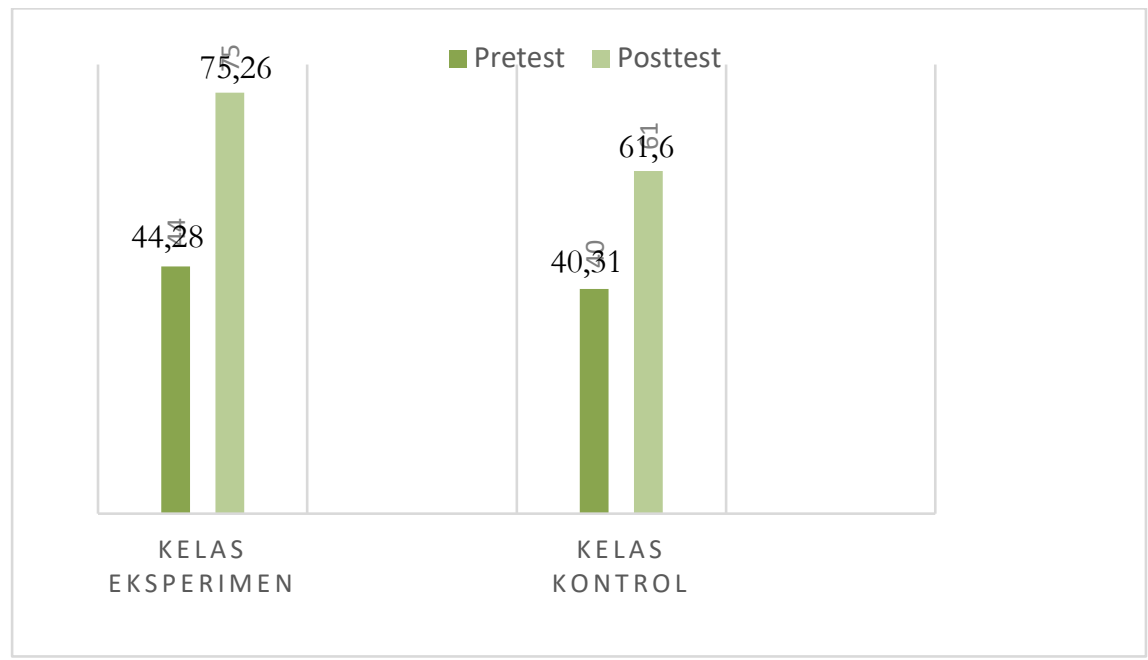

Gambar 1. Nilai kemampuan pemecahan masalah matematis

Berdasarkan Diagram 1 tersebut terlihat bahwa nilai rata-rata pretest kemampuan pemecahan masalah matematis siswa kelas eskperimen $(44,28)$ dan kelas kontrol $(40,31)$ hanya memiliki perbedaan 3,97 poin yang berarti tidak terdapat perbedaan yang signifikan. Hal ini disebabkan karena kemampuan siswa pada masing-masing kelas adalah homogen dan belum memperoleh perlakuan.

Kondisi ini diperkuat dengan analisis data yang digunakan peneliti untuk menguji kemampuan pemecahan masalah matematis awal dari hasil pretest yaitu menggunakan uji t. Namun sebelum dilakukan uji t peneliti melakukan uji prasyarat yaitu uji normalitas dan uji homogenitas. Adapun secara rinci hasil uji normalitas dan uji homogenitas disajikan dalam Tabel 1 dan 2 berikut:

Tabel 1. Hasil Uji Normalitas Pretest Kemampuan Pemecahan Masalah Matematis

\begin{tabular}{cccc}
\hline Kelas & $\boldsymbol{X}_{\text {hitung }}$ & $\boldsymbol{x}_{\text {tabel }}$ & Kriteria \\
\hline Eksperimen & 10.668 & 11.070 & Normal \\
Kontrol & 6,743 & 11.070 & Normal \\
\hline
\end{tabular}

Tabel 2. Hasil Uji Homogenitas Pretest Kemampuan Pemecahan Masalah Matematis

\begin{tabular}{ccccc}
\hline Nilai Varians & \multicolumn{2}{c}{ Kelas } & $\boldsymbol{F}_{\text {hitung }}$ & $\boldsymbol{F}_{\text {tabel }}$ \\
\cline { 2 - 3 } Sampel & Eksperimen & Kontrol & & \\
\hline $\boldsymbol{S}^{\mathbf{2}}$ & 272,712 & 194,630 & 1,40 & 1,77 \\
$\mathbf{N}$ & 35 & 35 & & \\
\hline
\end{tabular}

Karena data berdistribusi normal dan homogen maka selanjutnya dilakukan uji t untuk mengetahui ada tidaknya perbedaan kemampuan pemecahan masalah matematis awal dari kelas eksperimen dan control, seperti tampak pada Tabel 3 berikut: 
Tabel 3. Hasil Uji t Pretest Kemampuan Pemecahan Masalah Matematis

\begin{tabular}{ccl}
\hline $\boldsymbol{t}_{\text {hitung }}$ & $\boldsymbol{t}_{\text {tabel }}(\mathbf{5} \%)$ & Keterangan \\
\hline 0,303 & 1,668 & $H_{o}$ diterima \\
\hline
\end{tabular}

Berdasarkan hasil analisis data pretest yang dilakukan maka diperoleh $t_{\text {hitung }}=0,303$ dan $t_{\text {tabel }}=1,668$ berarti $t_{\text {hitung }}<t_{\text {tabel }}$ maka $H_{o}$ diterima dan $H_{a}$ ditolak. Jadi dapat disimpulkan bahwa tidak terdapat perbedaan kemampuan pemecahan masalah matematis siswa kelas eksperimen dengan siswa kelas kontrol sebelum penerapan model pembelajaran Problem Based Learning.

Pada Gambar 1, setelah kelas eksperimen diberikan perlakuan dengan menerapkan model pembelajaran Problem Based Learning maka perbedaan nilai rata-rata kemampuan pemecahan masalah matematis siswa meningkat sebesar 13,66 poin. Pada kelas ekperimen sendiri terjadi peningkatan nilai sebesar 30,98 poin antara sebelum dan sesudah perlakuan, sedangkan pada kelas kontrol hanya meningkat sebesar 21,29 poin. Kondisi ini diperkuat dengan hasil perhitungan nilai posttest kemampuan pemecahan masalah matematis siswa antara kelas eksperimen dan kontrol seperti tampak pada Tabel 4, 5 dan 6 berikut:

Tabel 4. Hasil Uji Normalitas Posttest Kemampuan Pemecahan Masalah Matematis

\begin{tabular}{cccc}
\hline Kelas & $\boldsymbol{X}_{\text {hitung }}$ & $\boldsymbol{x}_{\text {tabel }}$ & Kriteria \\
\hline Eksperimen & 9,523 & 11,070 & Normal \\
Kontrol & 5,043 & 11,070 & Normal \\
\hline
\end{tabular}

Tabel 5. Hasil Uji Homogenitas Posttest Kemampuan Pemecahan Masalah Matematis

\begin{tabular}{ccccc}
\hline Nilai Varians & \multicolumn{2}{c}{ Kelas } & $\boldsymbol{F}_{\text {hitung }}$ & \multirow{2}{*}{$\boldsymbol{F}_{\text {tabel }}$} \\
\cline { 2 - 3 } Sampel & Eksperimen & Kontrol & & \\
\hline $\boldsymbol{S}^{\mathbf{2}}$ & 246,364 & 154,953 & 1,58 & 1,77 \\
$\mathbf{N}$ & 35 & 35 & & \\
\hline
\end{tabular}

Tabel 6. Tabel uji Anova Posttest Kemampuan Pemecahan Masalah Matematis

\begin{tabular}{cccccc}
\hline Sumber Varians & JK & Dk & RJK & $\boldsymbol{F}_{\text {hitung }}$ & $\boldsymbol{F}_{\text {tabel }}$ \\
\hline Antar Kolom (A) & 7082,794 & 2 & 3541,397 & 15,01 & 3,14 \\
Antar Baris (B) & 3264,057 & 1 & 3264,057 & 13,83 & 3,99 \\
Interaksi (A×B) & $-922,756$ & 2 & $-461,378$ & $-1,95$ & 3,14 \\
Dalam & 15102,33 & 64 & 235,973 & & \\
Jumlah & 24526,42 & 69 & 6580,049 & & \\
\hline
\end{tabular}

Berdasarkan hasil analisis data yang dilakukan diperoleh Uji hipotesis I (Antar Baris) yang menunjukkan bahwa nilai $F_{(\mathrm{B}) \text { bitung }}=13,83$. Karena $F_{(\mathrm{B}) \text { bitung }}=13,83>F_{(\mathrm{B}) \text { tabel }}=3,99$, maka $\mathrm{H}_{\mathrm{o}}$ ditolak dan $\mathrm{H}_{\mathrm{a}}$ diterima. Artinya terdapat perbedaan kemampuan pemecahan masalah matematis antara siswa yang mengikuti model pembelajaran Problem Based Learning dengan siswa yang mengikuti model pembelajaran langsung. Hal ini menunjukkan bahwa model pembelajaran problem based learning memberikan pengaruh yang baik terhadap kemampuan 
siswa dalam memecahkan masalah matematis (Sugiyono, 2015; Zuraida \& Karyati, 2018; Yusri, 2018).

Model pembelajaran problem based learning yang menghadapkan siswa pada masalah (soal) melalui lembar kerja siswa yang dikerjakan secara berkelompok dan lembar evaluasi yang dikerjakan secara mandiri yang bisa membantu siswa untuk terampil dan meningkatkan kemampuannya dalam memecahkan masalah matematis. Hal ini sejalan dengan pendapat yang dikemukakan oleh Gafur et al. (2015) yang menjelaskan bahwa seseorang harus memiliki pengalaman dalam memecahkan berbagai masalah untuk memperoleh kemampuan dalam pemecahan masalah.

Pada proses pembelajaran dengan menggunakan model Problem Based Learning ini siswa dihadapkan dengan masalah matematis dan siswa memecahkan masalah yang diberikan sesuai dengan indikator kemampuan pemecahan masalah yang dirumuskan berdasarkan Polya, yaitu memahami masalah, menyusun rencana pemecahan masalah, melaksanakan rencana pemecahan masalah dan mengecek kembali jawaban yang diperoleh serta memberikan kesimpulan terhadap penyelesaian masalah (Setiani \& Priansa, 2018). Untuk melihat lebih jelasnya, peneliti akan menjabarkan soal kemampuan pemecahan masalah matematis siswa dan jawaban siswa untuk lima butir soal yang diberikan, yaitu sebagai berikut:

\section{Soal Kemampuan Pemecahan Masalah Matematis Nomor 1}

Pada butir soal nomor 1 kemampuan pemecahan masalah matematis dengan materi penyelesaian sistem persamaan linear dua variabel dengan metode grafik. Adapun bentuk soal nomor 1 yaitu: "Coba pahami masalah di bawah ini, kemudian nyatakan terlebih dahulu mana yang belum diketahui dan ditanya. "Fifa pergi ke warung untuk membeli 2 cup teh rio dan 1 buah roti biskuit dengan harga Rp. 6.000 dan di warung yang sama Santi membeli 2 cup teh rio dan 4 bungkus roti biskuit dengan harga Rp.12.000. Buatlah model matematikanya dan tentukan berapa harga 1 сир teh rio dan harga 1 buah roti biskuit. Selesaikan dengan metode grafik. Kemudian periksa kembali jawaban yang kamu peroleh!”. Berikut hasil lembar jawaban salah satu siswa pada soal nomor 1. 


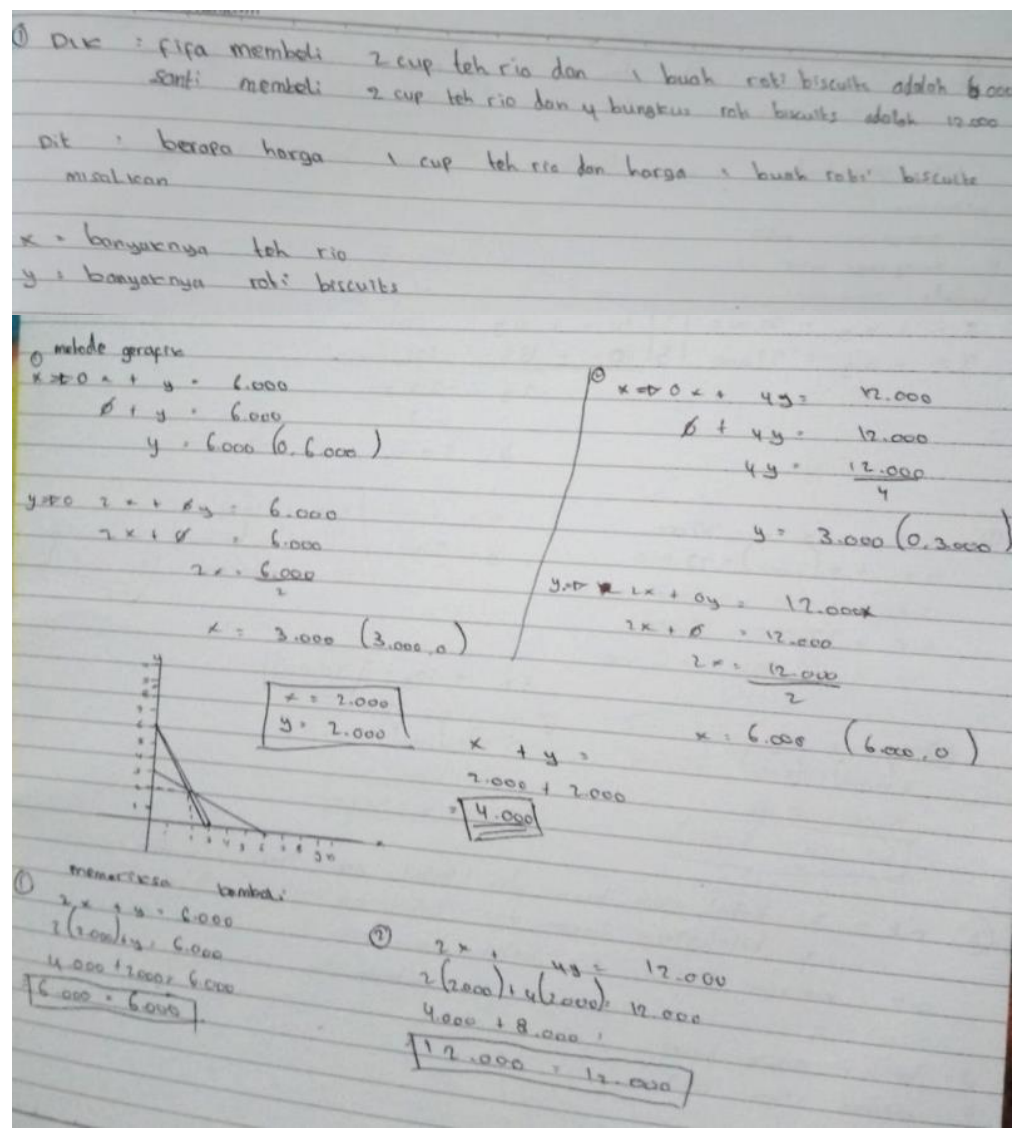

Gambar 1. Lembar Jawaban Siswa Nomor 1

Berdasarkan jawaban siswa terhadap soal kemampuan pemecahan masalah nomor 1, tampak bahwa siswa sudah bisa memahami masalah dengan menuliskan unsur yang diketahui dan ditanyakan dari soal tersebut, tetapi apa yang ditanyakan dari soal berbeda dengan yang ditulis oleh siswa. Siswa juga sudah mampu merencanakan penyelesaian masalah dengan baik, namun masih ada juga beberapa siswa yang belum mampu dalam menyatakan situasi ke dalam model matematika dan bingung dalam menyelesaikan soal.

Hal ini juga terlihat dari jawaban beberapa siswa ketika siswa melaksanakan rencana pemecahan masalah tersebut. Terdapat sedikit kesalahan siswa yaitu karena ketidaktelitian siswa atau siswa tidak memahami kalimat soal. Namun ada juga siswa yang sudah mampu menyelesaikan soal dengan benar dan memilih prosedur yang tepat dalam menyelesaikan masalah dengan merubah kalimat sehari-hari ke dalam model matematika. Beberapa siswa sudah melakukan pengecekan kembali terhadap hasil namun sebagian besar kesalahan yang sering juga terjadi karena siswa tidak melakukan pengecekan kembali terhadap hasil jawaban yang diperolehnya, sehingga simpulan yang diberikan pun kurang tepat. 


\section{Soal Kemampuan Pemecahan Masalah Matematis Nomor 2}

Pada butir soal nomor 2 kemampuan pemecahan masalah matematis dengan materi penyelesaian sistem persamaan linear dua variabel dengan metode campuran. Adapun bentuk soal nomor 2 yaitu "Di sebuah lapangan, terdapat turnamen bola voli dimana seorang tukang parkir mendapat uang sebesar Rp. 50.000,00 dari 5 buah mobil dan 4 buah motor, sedangkan dari 2 buah mobil dan 3 buah motor ia mendapat uang sebesar Rp. 27.000,00. Jika terdapat 5 mobil dan 10 motor, berapa banyak uang parkir yang ia peroleh? Selesaikanlah dengan metode campuran!

a. Catatlah informasi yang kamu peroleh, nyatakan yang belum diketahui dan ditanya kemudian buatlah model matematikanya pada masalah tersebut!

b. Periksa kembali jawaban yang kamu peroleh dengan memasukkan nilai ke persamaan!

Berikut hasil lembar jawaban salah satu siswa pada soal no 2 .

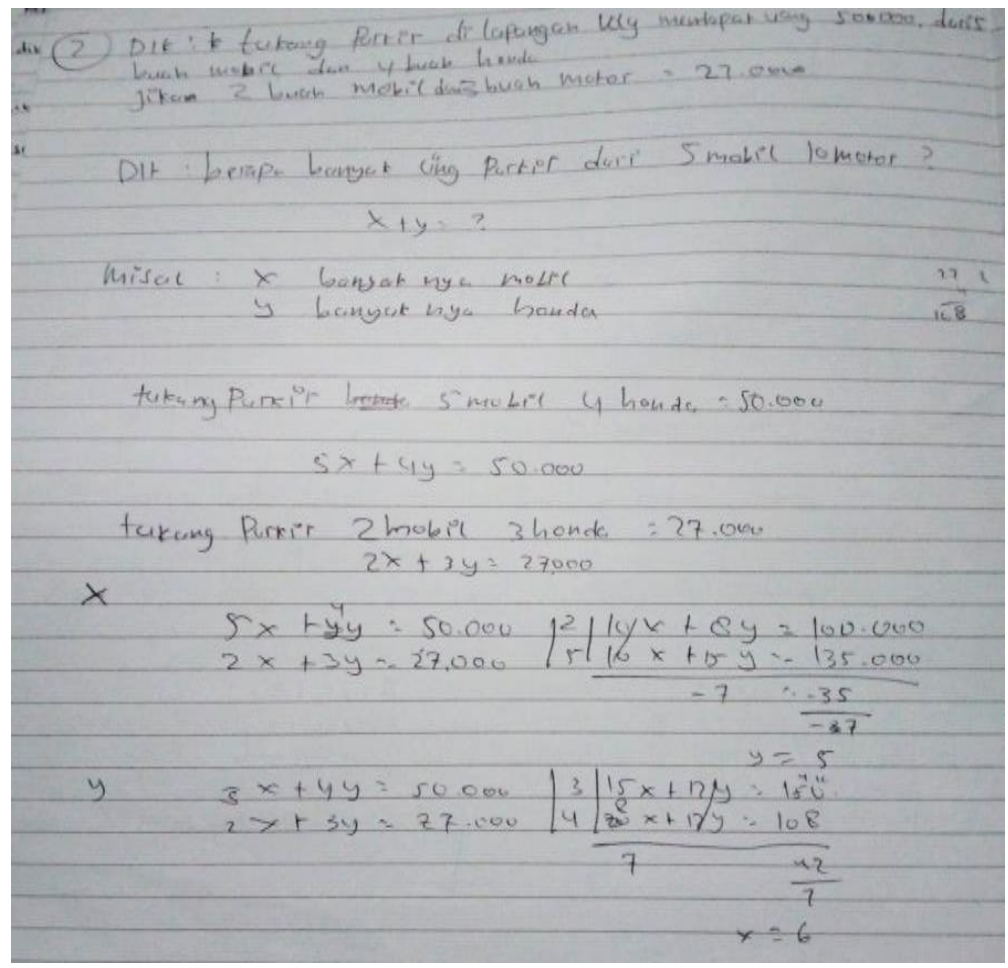

Gambar 2. Lembar Jawaban Siswa No.2

Pada soal ini, beberapa siswa telah memahami unsur-unsur yang diketahui dan ditanyakan dari soal tersebut. Selanjutnya siswa juga merencanakan pemecahan masalah, namun ada juga siswa tidak menuliskan konsep yang berkaitan dengan soal tersebut, tetapi langsung dilanjutkan dengan pertanyaan soal. Selanjutnya dalam melakukan perhitungan dan memberikan simpulan diperoleh hasil yang benar. 
Namun, kesalahan beberapa siswa dalam mengerjakan soal ini adalah rencana penyelesaian masalah yang digunakan tidak jelas, karena siswa tidak menjelaskan materi yang berkaitan dengan masalah tersebut dan tidak menuliskan model matematika dalam melakukan penyelesaian masalah matematis. Selanjutnya sedikit kesalahan juga terjadi dari beberapa siswa dalam proses perhitungan. Hal ini disebabkan ketidaktelitian siswa dalam menyelesaikan masalah sehingga hasil yang diperoleh kurang tepat. Sebagian besar kesalahan yang sering juga terjadi karena siswa tidak melakukan pengecekan kembali terhadap hasil jawaban yang diperolehnya, sehingga simpulan yang diberikan pun kurang tepat.

\section{Soal Kemampuan Pemecahan Masalah Matematis Nomor 3}

Butir soal nomor tiga terkait dengan penyelesaian sistem persamaan linear dua variabel dengan metode substitusi. Adapun bentuk soalnya yaitu: "Harga 3 botol aqua besar dan 1 botol aqua kecil Rp. 11.000,00. Sedangkan harga 2 botol aqua besar dan 1 botol aqua kecil Rp. 8.000,00. Berapakah harga 2 botol aqua besar dan 2 botol aqua kecil? Selesaikan dengan metode substitusi! Nyatakan yang diketahui dan ditanya, kemudian buatlah model matematikanya dan periksa kembali jawaban yang kamu peroleh!". Berikut hasil lembar jawaban salah satu siswa pada soal nomor 3.

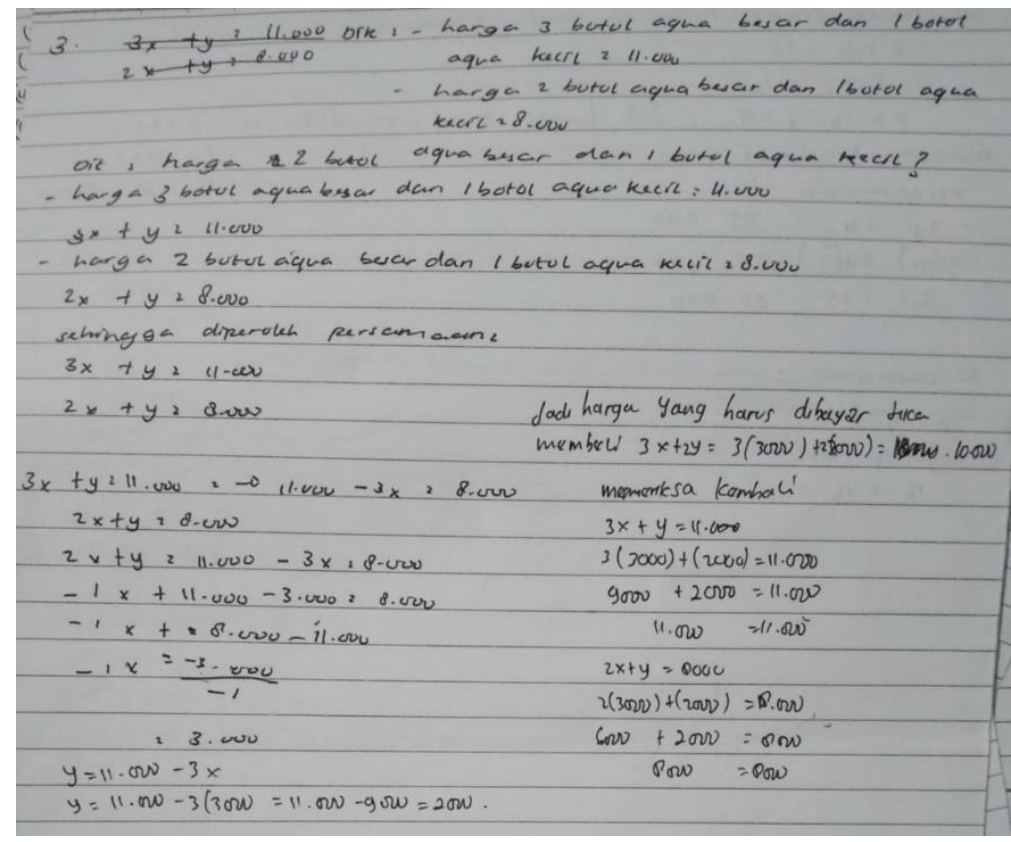

Gambar 3. Lembar Jawaban Siswa Nomor 3

Pada soal ini, beberapa siswa telah memahami unsur-unsur yang diketahui dan ditanyakan dari soal tersebut dengan baik, merencanakan pemecahan masalah. Selanjutnya siswa juga membuat melaksanakan pemecahan masalah dan dalam melakukan perhitungan dan memberikan simpulan diperoleh hasil yang benar. Namun kesalahan yang dilakukan 
beberapa siswa terletak pada proses mensubstitusikan persamaan sehingga hasil yang diperoleh kurang tepat.

\section{Soal Kemampuan Pemecahan Masalah Matematis Nomor 4}

Butir soal nomor 4 terkait dengan penyelesaian sistem persamaan linear dua variabel dengan metode eliminasi. Adapun bentuk soalnya yaitu, "Pada lahan parkir suatu rumah makan terdapat mobil dan motor yang semuanya berjumlah 21 kendaraan. Sedangkan jumlah roda itu ada 64 buah. Tentukan ada berapa banyak mobil dan motor di lahan parkir tersebut? Untuk menjawab masalah tersebut nyatakan mana yang belum diketahui dan ditanyakan kemudian buatlah model matematikanya dan selesaikan dengan metode eliminasi kemudian periksa hasil yang kamu peroleh!”. Berikut hasil lembar jawaban salah satu siswa pada soal nomor 4 .

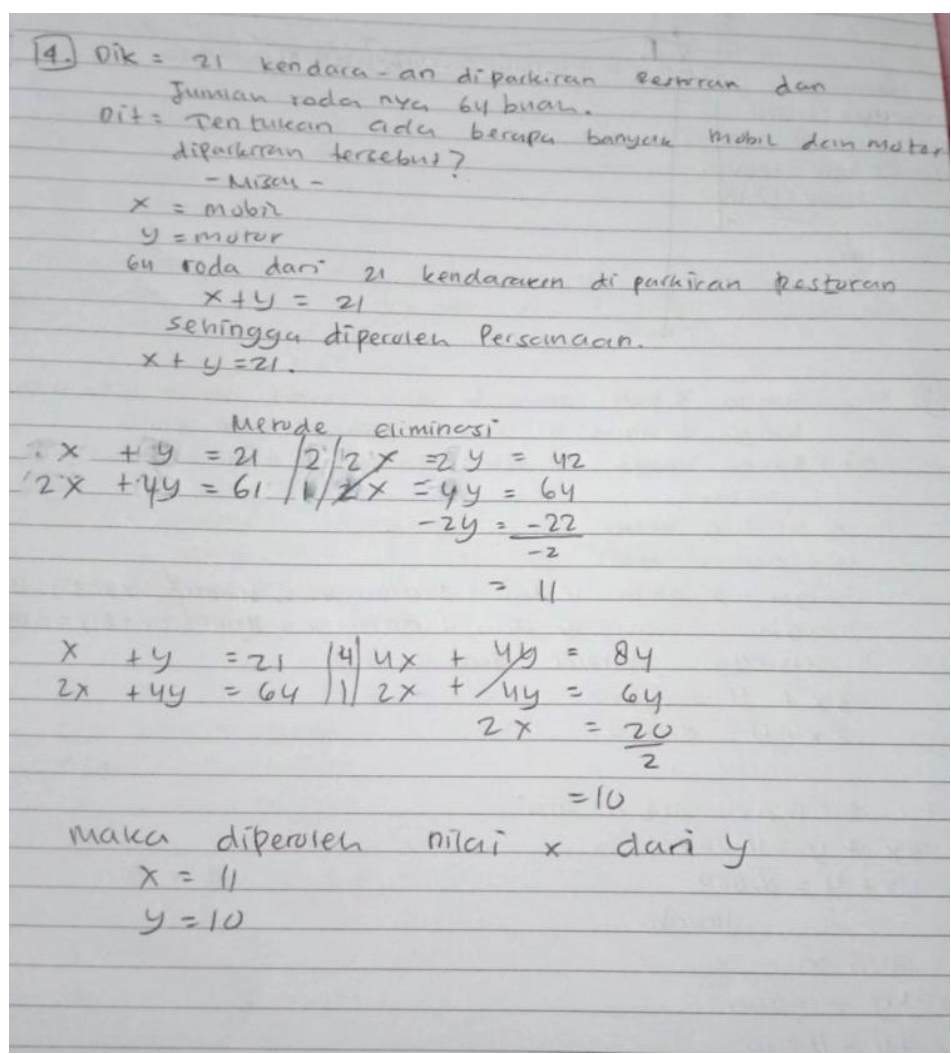

Gambar 4. Lembar Jawaban Siswa Nomor 4

Pada soal keempat ini, beberapa siswa sudah mampu menyelesaikan soal dengan benar dan siswa juga telah memahami unsur-unsur yang diketahui dan ditanyakan dari soal tersebut, merencanakan pemecahan masalah. Namun masih ada beberapa siswa yang kurang tepat dalam membuat model matematika. Selanjutnya siswa juga dapat melakukan perhitungan dan memberikan simpulan dan pengecekan diperoleh hasil yang benar. Namun masih terdapat 
beberapa siswa yang tidak melakukan pemeriksaan hasil dan siswa juga masih ada yang salah dalam memeriksa kembali hasil kebenaran jawaban yang diperolehnya.

\section{Soal Kemampuan Pemecahan Masalah Matematis Nomor 5}

Butir soal nomor 5 terkait dengan penyelesaian sistem persamaan linear dua variabel dengan metode campuran. Adapun bentuk soalnya yaitu: "Seorang tukang bangunan membeli 3 kaleng cat tembok dan 4 buah kuas dengan harga Rp. 55.000. Sedangkan harga 1 kaleng cat dan 1 kuas adalah Rp. 16.000,00.

a. Catatlah semua informasi yang kamu peroleh, kemudian nyatakan yang belum diketahui dan ditanya!

b. Buatlah model matematikanya pada masalah tersebut!

c. Berapa harga 2 kaleng cat dan 3 kuas? Kerjakan dengan metode campuran!

d. Periksa kembali jawaban yang kamu peroleh dengan memasukkan nilai ke persamaan!

Berikut hasil lembar jawaban salah satu siswa pada soal nomor 5.

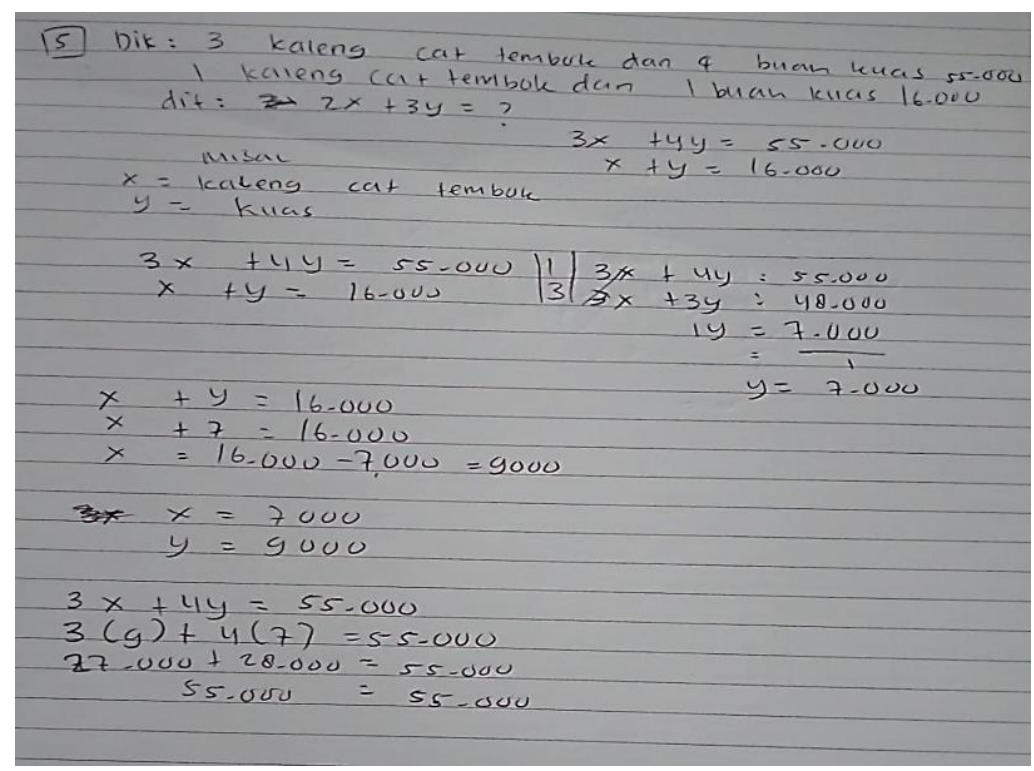

Gambar 5. Lembar Jawaban Siswa Nomor 5

Pada soal nomor 5 ini, beberapa siswa sudah mampu menyelesaikan soal dengan benar, namun terdapat beberapa siswa yang tidak menuliskan konsep yang berkaitan dengan soal tersebut, tetapi langsung dilanjutkan dengan pertanyaan soal. Selanjutnya dalam melakukan perhitungan dan memberikan simpulan diperoleh hasil yang benar. Kesalahan siswa dalam mengerjakan soal ini adalah rencana penyelesaian masalah yang digunakan tidak jelas, karena siswa tidak menuliskan model matematika yang digunakan dalam melakukan penyelesaian masalah matematis. Untuk pengecekan terhadap hasil penyelesaian sudah ada siswa yang 
melakukan pengecekan hasil dengan baik dan benar, namun masih ada juga beberapa siswa yang tidak melakukan pengecekan terhadap hasil yang diperolehnya.

Selanjutnya pembahasan difokuskan untuk mengetahui ada tidaknya perbedaan kemampuan pemecahan masalah matematis pada siswa yang memiliki self regulated learning tinggi, sedang, dan rendah serta ada tidaknya interaksi antara model pembelajaran problem based learning terhadap kemampuan pemecahan masalah matematis siswa. Oleh karena itu siswa diberikan angket self regulated learning, kemudian siswa dikelompokkan berdasarkan self regulated learning tinggi, sedang dan rendah. Hasil perhitungan pengelompokan siswa berdasarkan self regulated learning yang disajikan secara rinci dalam Tabel 7 berikut:

Tabel 7. Hasil Pengelompokan Siswa berdasarkan Self Regulated Learning

\begin{tabular}{cccc}
\hline Kriteria Self Regulated Learning & Keterangan & Eksperimen & Kontrol \\
\hline$S R L \geq 78,77$ & Tinggi & 7 Orang & 6 Orang \\
$66,33<S R L<78,77$ & Sedang & 24 Orang & 20 Orang \\
$S R L \leq 66,33$ & Rendah & 4 Orang & 9 Orang \\
\hline
\end{tabular}

Berdasarkan hasil analisis data self regulated learning terlihat bahwa sebagian besar siswa memiliki kemampuan self regulated learning sedang baik pada kelas eksperimen maupun pada kelas kontrol. Kemudian setelah siswa dikelompokkan berdasarkan self regulated learning berdasarkan Uji hipotesis II (Antar Kolom) pada Tabel 6 tampak bahwa diperoleh nilai $F_{(\mathrm{A}) \text { bitung }}=15,01$. Karena $F_{(\mathrm{A}) \text { bitung }}=15,01>F_{(\mathrm{A}) \text { tabel }}=3,14$, maka $\mathrm{H}_{\mathrm{o}}$ ditolak dan $\mathrm{H}_{\mathrm{a}}$ diterima. Artinya terdapat perbedaan kemampuan pemecahan masalah matematis antara siswa yang memiliki self regulated learning tinggi, self regulated learning sedang, dan self regulated learning rendah. Kondisi ini juga ditunjukkan dari perolehan nilai rata-rata kemampuan pemecahan masalah matematis siswa kelas eksperimen yang memiliki self regulated learning tinggi sebesar 90,14, sedang sebesar 73,75, dan rendah sebesar 58,25. Hal ini juga terjadi pada kelas kontrol dengan nilai rata-rata kemampuan pemecahan masalah matematis siswa yang memiliki self regulated learning tinggi sebesar 81,5, sedang sebesar 60,35, dan rendah sebesar 51,11. Hal ini sesuai dengan pendapat Zuraida dkk (2017) yang menyatakan bahwa self regulated learning dapat meningkatkan hasil dari proses pembelajaran.

Namun hasil di atas juga menunjukkan bahwa tidak ada hubungan antara model pembelajaran yang diberikan dengan self regulated learning terhadap kemampuan pemecahan masalah matematis siswa, karena baik pada kelas eksperimen maupun kelas kontrol terjadi perbedaan nilai rata-rata kemampuan pemecahan matematis di setiap tingkat self regulated learning. Pada kedua kelas siswa dengan self regulated learning tinggi memiliki nilai nilai rata-rata kemampuan pemecahan matematis paling baik dibanding yang lain. Kondisi ini diperkuat 
berdasarkan Uji hipotesis III (Antar Kolom dan Baris) pada Tabel 6 yang menunjukkan bahwa $F_{(\mathrm{AxB}) \text { bitung }}=-1,95$. Karena $F_{(\mathrm{AxB}) \text { bitung }}=-1,95<F_{(\mathrm{AxB}) \text { tabel }}=3,14$, maka $\mathrm{H}_{\mathrm{a}}$ ditolak dan $\mathrm{H}_{\mathrm{o}}$ diterima. Artinya tidak terdapat interaksi antara model pembelajaran dan self regulated learning terhadap kemampuan pemecahan masalah matematis siswa. Hasil penelitian ini relevan dengan hasil penelitian yang dilakukan oleh Sarbia, dkk (2017) yang menunjukkan bahwa tidak terdapat interaksi antara model pembelajaran dan self regulated learning siswa terhadap kemampuan pemecahan masalah matematika.

\section{SIMPULAN DAN SARAN}

Berdasarkan hasil penelitian yang sudah dipaparkan dapat disimpulkan bahwa: 1) Terdapat perbedaan kemampuan pemecahan masalah matematis antara siswa yang mengikuti model pembelajaran problem based learning dengan siswa yang mengikuti model pembelajaran langsung, 2) Terdapat perbedaan kemampuan pemecahan masalah matematis antara siswa yang memiliki self regulated learning tinggi, self regulated learning sedang, dan self regulated learning rendah, dan 3) Tidak terdapat interaksi antara model pembelajaran dan self regulated learning terhadap kemampuan pemecahan masalah matematis siswa.

Saran yang dapat diberikan untuk penelitian selanjutnya, antara lain: (1) diharapkan memperhitungkan waktu berjalannya diskusi dan presentasi sesuai dengan jam pelajaran yang disediakan sekolah, agar seluruh tahapan dalam model pembelajaran problem based learning terlaksana dengan baik pada setiap pertemuan, (2) memastikan setiap siswa memiliki buku pegangan matematika, sehingga mereka memiliki referensi tambahan yang memudahkan dalam mengikuti proses pembelajaran, (3) memotivasi siswa agar berani menyampaikan pendapat dan berperan aktif dalam kegiatan pembelajaran.

\section{DAFTAR RUJUKAN}

Amir, Z. \& Risnawati. (2015). Psikologi Pembelajaran Matematika. Yogyakarta: Aswaja Pressindo.

Azizah, A., Maimunah, M., \& Roza, Y. (2019). Kemampuan Pemecahan Masalah Matematis Siswa pada Materi Peluang Berdasarkan Self-Regulated Learning (S-RL). JRPM (Jurnal Review Pembelajaran Matematika), 4(1), 23-31. https://doi.org/10.15642/jrpm.2019.4.1.23-31.

Gafur, I. M., et al. (2015). Meningkatkan Kemampuan Pemecahan Masalah Open Ended Siswa Kelas VII-2 SMPN 3 Kulisusu melalui Pendekatan Pengajuan Masalah pada Pokok Bahasan Segi Empat. Jurnal Penelitian Pendidikan Matematika, 3(1), 75-90.

Hartono, (2019). Metodologi Penelitian. Pekanbaru: Zanafa Publishing. 
Hendriana, H. dkk. (2017). Hard Skills dan Soft Skills Matematika Siswa. Bandung: PT Rafika Kencana Aditama.

Kurnila, V., Jau, M., Fedi, S., \& Kurniawan, Y. (2018). Pemecahan Masalah dengan Pendekatan Saintifik dan Koperatif Tipe NHT, serta Peningkatan Kemampuan Komunikasi Matematika Siswa SMP. JRPM (Jurnal Review Pembelajaran Matematika), 3(2), 132-145. https://doi.org/10.15642/jrpm.2018.3.2.132-145.

Lestari, K. E., \& Yudhanegara, M.R. (2015). Penelitian Pendidikan Matemaika. Bandung: Refika Aditama.

Nadhifah, G \& Afriansyah, E.A. (2016). Peningkatan Kemampuan Pemecahan Masalah Matematis Siswa dengan Menerapkan Model Pembelajaran Problem Based Learning dan Inquiry. Jurnal Mosharafa: Jurnal Pendidikan Matematika, 5(1). 33-44

Nisak, K. \& Istiana, A. (2017). Pengaruh Pembelajaran PBL (Problem Based Learning) Terhadap Kemampuan Pemecahan Masalah Matematis Siswa. Jurnal Kajian Pendidikan Matematika, 3(1), 91-98.

Riati, T. \& Farida, N., (2017). Pengaruh Model Pembelajaran Quantum Learning Terhadap Kemampuan Pemecahan Masalah Matematika Siswa Kelas VIII SMP PGRI 02 Ngajum. Mathematics Education Journal. 1(1), 15-21. https://doi.org/10.21067/pmej.v1i1.1999.

Permendikbud. (2006). Permendikbud RI Nomor 21 Tahun 2006 Tentang Standar ISI Pendidikan Dasar dan Menengah. Jakarta.

Sanjaya, W. (2006). Strategi Pembelajaran Berorientasi Standar Proses Pendidikan. Bandung: Karisma Putra Utama.

Sarbia, et al. (2017). Pengaruh Model Pembelajaran Problem Based Learning dan Pembelajaran Kooperatif TGT Terhadap Kemampuan Pemecahan Masalah Matematik Berdasarkan Self Regulated Learning Siswa SMP. Jurnal Pendidikan Matematika, 8(1), 86-96. http://ojs.uho.ac.id/index.php/ipm.

Setiani, A. \& Priansa, D.J. (2018). Manajemen Peserta Didik Dan Model Pembelajaran: Cerdas, Kreatif Dan Inovatif. Bandung: Alfabeta.

Sugiyono. (2015). Metode Penelitian Pendidikan Kuantitatif, Kualitatif dan R\&D. Bandung: Alfabeta.

Syah, Muhibbin. (2009). Psikologi Belajar. Depok: Raja Grafindo Persada.

Yusri, A.Y. (2018). Pengaruh Model Pembelajaran Problem Based Learning Terhadap Kemampuan Pemecahan Masalah Matematis Siswa SMP VII Pangkajene. Jurnal Mosharafa: Jurnal Pendidikan Matematika, 7(1), 51-62.

Zuraida, D. A., dkk. (2017). "Meningkatkan Self Regulated Learning Siswa Melalui Pendekatan Problem Based Learning dengan Setting Numbered Heads Together", Seminar Matematika Dan Pendidikan Matematika UNY, ISBN. 978-602-73403-2-9. http://seminar.uny.ac.id/semnasmatematika/sites/seminar.uny.ac.idsemnasmatemati $\mathrm{ka} /$ files/full/M-

Zuraida, D. A, \& Karyati. (2018). The effectiveness comparison problem based learning model with NHT and TPS type on plane solid figure. Jurnal Riset Pendidikan Matematika, 5 (2), 254-263. 